\author{
Кищун В. А. \\ Луцький національний технічний університет
}

\title{
АВАРІЙНІСТЬ НА ДОРОГАХ УКРАЇНИ: ОЧІКУВАННЯ, ЩО НЕСПРАВДИЛИСЯ
}

\begin{abstract}
Метою дослідження у роботі стало визначення фактичних показників стану аварійності на вітчизняних дорогах та порівняння їх з очікуваними, що були затверджені у Державних програмах підвищення рівня безпеки дорожнього руху на періоди до 2016 і 2020 років, а також аналіз очікуваних показників, наведених у Державній програмі підвищення рівня безпеки дорожнього руху на період до 2023 року.

Стан аварійності оцінювався за такими показниками, як кількість загиблих і травмованих на 100 тис. населення (соціальний ризик), кількість загиблих на 100 тис. транспортних засобів (транспортний ризик), а також трьома показниками, що характеризують тяжкість пригоди: кількість загиблих на 100 постраждалих та кількість загиблих і травмованих на 100 дорожньо-транспортних пригод (ДТП). У процесі досліджень визначалися фактичні показники аварійності в Україні у 2015-2020 роках. Як наслідок було встановлено, що фактичні показники соціального і транспортного ризиків у ці роки були гірші за очікувані і лише кількість загиблих внаслідок ДТП на 100 постраждалих була меншою або знаходилася на одному рівні.

Певне неузгодження запланованих очікуваних результатів спостерігається у Державній програмі підвищення рівня безпеки дорожнього руху в Україні на період до 2023 року. Якщо порівняти числа суміжних 2020 і 2021 років, то очікувані результати за трьома показниками невиправдано зросли і лише кількість загиблих внаслідок ДТП на 100 постраждалих у 2021 і наступних роках передбачається меншою. Ще більша неузгодженість спостерігається, коли порівняти фактичні показники 2020 року з очікуваними 2021-го; прогнозується гірша ситуація на українських дорогах ніж та, що $є$ у дійсності. Аналогічно неузгодженими виглядають два нових показники, що оцінюють рівень тяжкості наслідків пригод - це кількість загиблих і травмованих на 100 ДТП.

В Україні статистика щодо загибелі і травмування людей внаслідок дорожньо-транспортних пригод залишається достатньо високою, як для європейського регіону. Аналіз стану аварійності на вітчизняних дорогах за 2015-2020 роки показав, що за трьома показниками з чотирьох Державні програми з підвищення рівня БДР не були виконані, а закладені на майбутнє показники аварійності не сприятимуть покращенню ситуації у сфері забезпечення безпеки дорожнього руху.

Ключові слова: безпека дорожнього руху, транспортна стратегія, державні програми, зниження аварійності, очікувані показники аварійності, фактичні показники аварійності.
\end{abstract}

\section{ВСТУП}

Проблема підвищення безпеки автомобільного транспорту є надзвичайно важливою, оскільки аварійність на дорогах супроводжується значними збитками для економіки України. Соціальноекономічні втрати (прямі і побічні, пов'язані із тимчасовим або повним припиненням трудової діяльності людини) через дорожньо-транспортні пригоди - це майже 70 млрд гривень на рік, що становить приблизно $2 \%$ валового внутрішнього продукту [1].

Смертність внаслідок дорожньо-транспортних пригод (ДТП) в Україні є достатньо високою у європейському регіоні, що також викликає стурбованість. За останні шість років (2015-2020рр.) в Україні зареєстровано 938,74 тис. ДТП, із них 156 тис. пригод відбулося з постраждалими, у яких загинуло 21190 осіб та травмовано майже 195,5 тис. учасників дорожнього руху [2].

Разом 3 тим, сфера забезпечення безпеки дорожнього руху (БДР) не залишалася поза увагою держави продовж років незалежності, а особливо останні десять років. Було схвалено ряд стратегій та затверджено кілька Державних програм, виконання яких забезпечило б досягнення конкретних очікуваних результатів.

\section{АНАЛІЗ ЛІТЕРАТУРНИХ ДАНИХ ТА ПОСТАНОВКА ПРОБЛЕМИ}

20 жовтня 2010 року КМ України була схвалена «Транспортна стратегія України на період до 2020 року», метою якої стало визначення концептуальних засад формування та реалізації державної політики щодо забезпечення стабільного та ефективного функціонування галузі транспорту, створення умов для соціально-економічного розвитку країни, підвищення конкурентоспроможності національної економіки і рівня життя населення [3].

У документі зазначалося, що пріоритетами розвитку, зокрема, автомобільного транспорту є підвищення безпеки дорожнього руху та енергоефективності шляхом затвердження та виконання Державної цільової програми підвищення рівня БДР. Програмою передбачалося зниження рівня аварійності та важкості наслідків дорожньо-транспортних пригод, створення безпечних і комфортних умов руху транспортних засобів на вулично-дорожній мережі, а також удосконалення системи державного управління безпекою дорожнього руху на період до 2016 року [4]. 
Виконання передбачених заходів у повному обсязі мало б наблизити стан безпеки дорожнього руху до середньоєвропейського рівня шляхом зниження показників аварійності щодо соціального ризику (зменшення кількості загиблих унаслідок ДТП 3 11,1 до 7,5 на 100 тис. населення), транспортного ризику (зменшення кількості загиблих унаслідок ДТП з 35 до 18 на 100 тис. транспортних засобів) і зниження тяжкості наслідків ДТП (кількість загиблих унаслідок дорожньотранспортних пригод на 100 постраждалих) 3 15,3 до 13,4 [2, 4]. Очікувані результати виконання Державної цільової програми підвищення рівня безпеки дорожнього руху в Україні на період до 2016 року у 2015 і 2016 роках наведені у таблиці 1 [4].

У лютому 2017 року міжвідомчою робочою групою з реформування державної системи безпеки дорожнього руху був запропонований до обговорення проект Стратегії з підвищення рівня безпеки дорожнього руху. Проект розроблявся на виконання положень вищезгаданих «Транспортної стратегії України на період до 2020 року» та грудневих Рекомендацій парламентських слухань на тему: «Стан і перспективи забезпечення в Україні безпеки дорожнього руху», схвалених Постановою Верховної Ради України від 13 квітня 2016 року [5].

Метою Стратегії стало зниження рівня смертності внаслідок ДТП щонайменше на $30 \%$ до 2020 року, ступеня тяжкості наслідків ДТП для учасників дорожнього руху та зменшення соціальноекономічних втрат України від дорожньо-транспортного травматизму, а також запровадження ефективної системи управління безпекою дорожнього руху для забезпечення захисту життя та здоров’я населення. Розпорядженням КМ України від 14 червня 2017 р. №481-р Стратегія підвищення рівня безпеки дорожнього руху в Україні на період до 2020 року була схвалена [6].

Пізніше, Постановою КМ України від 25 квітня 2018 р. № 435 була затверджена Державна програма підвищення рівня безпеки дорожнього руху в Україні на період до 2020 року [7]. Метою програми передбачалося зниження в Україні рівня аварійності та ступеня тяжкості наслідків дорожньо-транспортних пригод, насамперед соціально-економічних, відповідно до цілей, визначених Стратегією підвищення рівня безпеки дорожнього руху в Україні на період до 2020 року та Генеральною Асамблеєю ООН у рамках Десятиліття дій з безпеки дорожнього руху 2011-2020 років. Зокрема, зниження на $30 \%$ рівня смертності внаслідок дорожньо-транспортних пригод, а також створення безпечних і комфортних умов усім учасникам дорожнього руху.

Програмою запроваджувався також додатковий показник аварійності, віднесений до групи соціального ризику - кількість травмованих внаслідок дорожньо-транспортних пригод на 100 тис. населення. Очікувані результати виконання Державної програми підвищення рівня БДР в Україні на період до 2020 року наведені також у таблиці 1.

Таблиця 1 - Очікувані результати виконання Державних програм підвищення рівня БДР у 2015-2023 роках $[4,7,14]$

\begin{tabular}{|c|c|c|c|c|c|c|c|c|c|c|}
\hline \multirow{2}{*}{$\begin{array}{c}\text { Найменування } \\
\text { завдання }\end{array}$} & \multirow{2}{*}{$\begin{array}{c}\text { Найменування показників } \\
\text { виконання завдання }\end{array}$} & \multicolumn{9}{|c|}{ Значення очікуваного показника } \\
\hline & & 2015 & 2016 & 2017 & 2018 & 2019 & 2020 & 2021 & 2022 & 2023 \\
\hline \multirow{2}{*}{$\begin{array}{l}\text { 1. Зниження } \\
\text { рівня } \\
\text { соціального } \\
\text { ризику }\end{array}$} & $\begin{array}{c}\text { Кількість загиблих внаслідок } \\
\text { дорожньо-транспортних } \\
\text { пригод } \\
\text { на } 100 \text { тис. населення }\end{array}$ & 8,7 & 7,5 & $6,4^{*}$ & 6,5 & 5,0 & 4,0 & 11,3 & 10,1 & 8,8 \\
\hline & $\begin{array}{c}\text { Кількість травмованих } \\
\text { внаслідок дорожньо- } \\
\text { транспортних пригод } \\
\text { на } 100 \text { тис. населення }\end{array}$ & - & - & - & 69,4 & 64,7 & 60,0 & 119,3 & 106,1 & 92,8 \\
\hline $\begin{array}{c}\text { 2. Зниження } \\
\text { рівня } \\
\text { транспортного } \\
\text { ризику }\end{array}$ & $\begin{array}{c}\text { Кількість загиблих внаслідок } \\
\text { дорожньо-транспортних } \\
\text { пригод } \\
\text { на } 100 \text { тис. транспортних } \\
\text { засобів }\end{array}$ & 24,0 & 18,0 & $14,0^{*}$ & 19,9 & 18,8 & 18,2 & 34,1 & 30,3 & 26,5 \\
\hline $\begin{array}{c}\text { 3. Зменшення } \\
\text { тяжкості } \\
\text { наслідків ДТП }\end{array}$ & $\begin{array}{c}\text { Кількість загиблих внаслідок } \\
\text { дорожньо-транспортних } \\
\text { пригод } \\
\text { на } 100 \text { постраждалих }\end{array}$ & 14,4 & 13,4 & $12,5^{*}$ & 9,8 & 9,6 & 9,3 & 7,8 & 6,9 & 6,1 \\
\hline
\end{tabular}

*Очікувані показники за 2017 рік були отримані шляхом побудови лінійних трендів за даними 2013-2016 років наведених у Державній програмі підвищення рівня БДР на період до 2016 року. 


\section{ЦІЛІ ТА ЗАДАЧІ ДОСЛІДЖЕННЯ}

Метою дослідження стало визначення фактичних показників стану аварійності на вітчизняних дорогах та порівняння їх з очікуваними, що були зазначені у Державних програмах підвищення рівня безпеки дорожнього руху на періоди до 2016 і 2020 років, а також аналіз очікуваних показників, наведених у Державній програмі підвищення рівня безпеки дорожнього руху на період до 2023 року.

\section{РЕЗУЛЬТАТИ ДОСЛІДЖЕНЬ}

Департамент Патрульної поліції України кожного року публікує у вигляді таблиць Excel статистику дорожньо-транспортних пригод (ДТП) за період з 01 січня по 31 грудня [1].

Статистичні дані у регіонах України відображаються у таблицях 27 позиціями серед яких 24 області, два міста (Київ і Сімферополь) і АР Крим. Присутня також графа «загалом». Починаючи 3 2015 року два рядки «АР Крим» і «Сімферополь» заповнюються «нулями», ще у двох областях Донецькій і Луганській, дані наводяться неповні, а лише 3, підконтрольних Україні територій.

Аварійність на дорогах може оцінюватися абсолютними, відносними, питомими та іншими показниками. До абсолютних показників відносяться загальна кількість дорожніх пригод, кількість загиблих і травмованих. До відносних показників зараховують кількість загиблих і травмованих на 100 тис. населення (соціальний ризик), кількість загиблих на 100 тис. транспортних засобів (транспортний ризик), а також показники, що характеризують важкість ДТП, зокрема кількість загиблих на 100 постраждалих. Для подальших досліджень були визначені фактичні відносні показники та показник важкості пригод в Україні за 2015-2020 роки. Результати розрахунків наведені у таблиці 2.

Під час формування таблиці 2 чисельність населення і автомобільного парку України з 2015 по 2020 роки бралися, відповідно, 3 джерел [8] і [9, 10, 11]. Слід також зауважити, що у доступних джерелах наводиться суперечлива інформація про чисельність вітчизняного парку автомобілів, тому показник кількості загиблих на 100 тис. транспортних засобів може відображати не зовсім реальний стан на вітчизняних дорогах [12].

Таблиця 2 - Відносні показники і показники важкості ДТП

\begin{tabular}{|c|c|c|c|c|}
\hline Рік & $\begin{array}{c}\text { Загиблих на } \\
100 \text { тис. населення }\end{array}$ & $\begin{array}{c}\text { Травмованих на } \\
100 \text { тис. населення }\end{array}$ & $\begin{array}{c}\text { Загиблих на } 100 \text { тис. } \\
\text { транспортних засобів }\end{array}$ & $\begin{array}{c}\text { Загиблих на } \\
100 \text { постраждалих }\end{array}$ \\
\hline 2015 & 9,36 & 73,90 & 27,73 & 11,24 \\
\hline 2016 & 8,01 & 78,93 & 22,18 & 9,21 \\
\hline 2017 & 8,10 & 81,81 & 23,64 & 9,00 \\
\hline 2018 & 7,95 & 73,27 & 26,10 & 9,79 \\
\hline 2019 & 8,24 & 78,12 & 25,90 & 9,54 \\
\hline 2020 & 8,51 & 76,81 & 23,26 & 9,97 \\
\hline
\end{tabular}

Для проведення порівняння були побудовані графіки за даними таблиць 1 і 2, що зображені на рисунку 1. Аналіз графіків засвідчив, що запланована кінцева мета Державних програм підвищення рівня БДР на період, як до 2016, так і до 2020 року залишилася недосяжною (див. рис. 1, а; б; в). Виняток становить лише такий показник, як кількість загиблих внаслідок ДТП на 100 постраждалих де фактичні показники в останні три роки близькі до очікуваних (див. рис. 1, г). Однак слід зауважити, що ці числа були апріорі завищені у Державній програмі 2010 року, тому отримати позитивний результат було не складно.

Відкориговані Державною програмою у 2018 році у напрямку збільшення фактичні показники кількості загиблих внаслідок ДТП на 100 тис. транспортних засобів, навіть при недоліках підрахунку автомобільного парку, перевищують очікувані на $31,2 \ldots 37,8 \%$ (див. рис. 1, в). Таким чином, аналіз стану аварійності на дорогах України у 2016-2020 роках показав, що за трьома показниками 3 чотирьох Державні програми з підвищення рівня БДР на кінець 2020 року не були виконані.

21 жовтня 2020 року Кабінет Міністрів на засіданні схвалив чергову Стратегію підвищення рівня безпеки дорожнього руху до 2024 року [13]. Метою стратегії передбачалося зниження рівня смертності внаслідок дорожньо-транспортних пригод щонайменше на 30\% до 2024 року, зниження ступеня тяжкості наслідків ДТП для учасників дорожнього руху та зменшення соціальноекономічних втрат від дорожньо-транспортного травматизму, а також запровадження ефективної системи управління безпекою дорожнього руху для забезпечення захисту життя та здоров'я населення.

На основі прийнятої стратегії було розроблено і затверджено у грудні 2020 року Державну 
програму підвищення рівня безпеки дорожнього руху в Україні на період до 2023 року, у якій було перераховано заходи та очікувані результати у разі ії виконання (див. табл. 1) [14]. Натомість, останні викликали певне здивування. Якщо порівняти числа у таблиці 1 суміжних 2020 і 2021 років, то очікувані результати за першими трьома показниками зросли і лише кількість загиблих внаслідок дорожньо-транспортних пригод на 100 постраждалих у 2021 і наступних роках передбачається меншою. Ще більша неузгодженість спостерігається, коли порівняти фактичні показники 2020 року 3 очікуваними 2021-го (див. табл. 1 і 2). Прогнозується (щоб не сказати планується) гірша ситуація на українських дорогах, ніж та, що є у дійсності.

Також суперечливими виглядають два нових показники, що оцінюють рівень тяжкості наслідків дорожньо-транспортних пригод - це кількість загиблих і травмованих на 100 ДТП. За розрахунками останніх п’яти років їх фактичні значення знаходяться у межах, відповідно, 2,1...2,2 і $19,0 \ldots 21,3$, що досить легко можна було вирахувати, однак у 2021 році очікуються чомусь невиправдано завищені результати 3,1 і 31,9 (див. табл. 3).

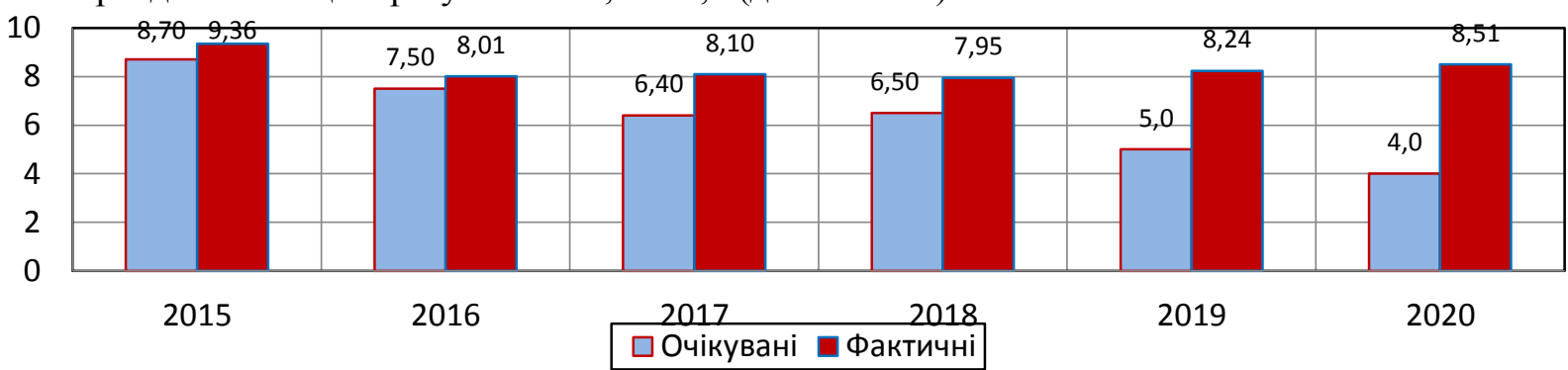

a)

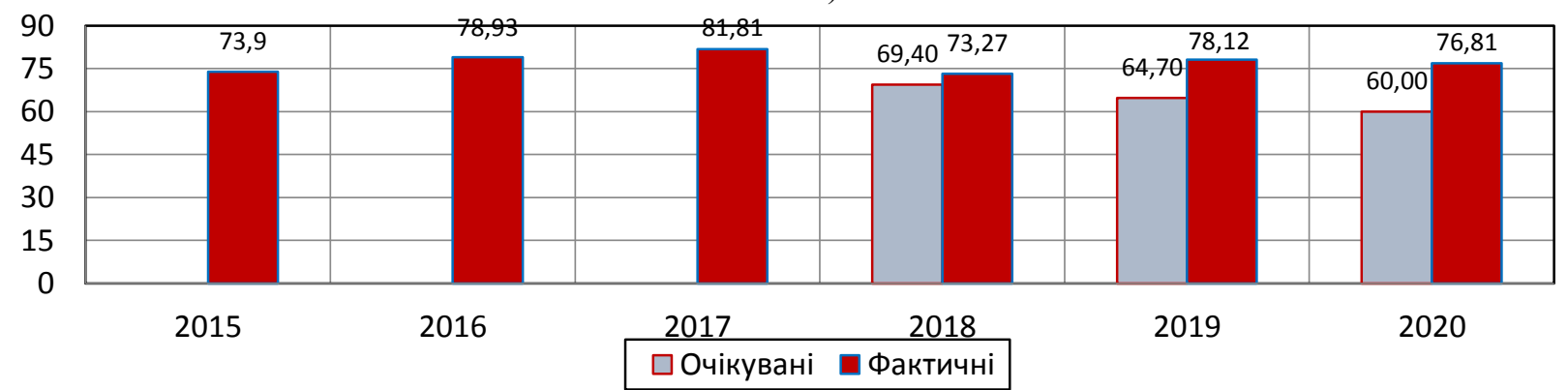

б)

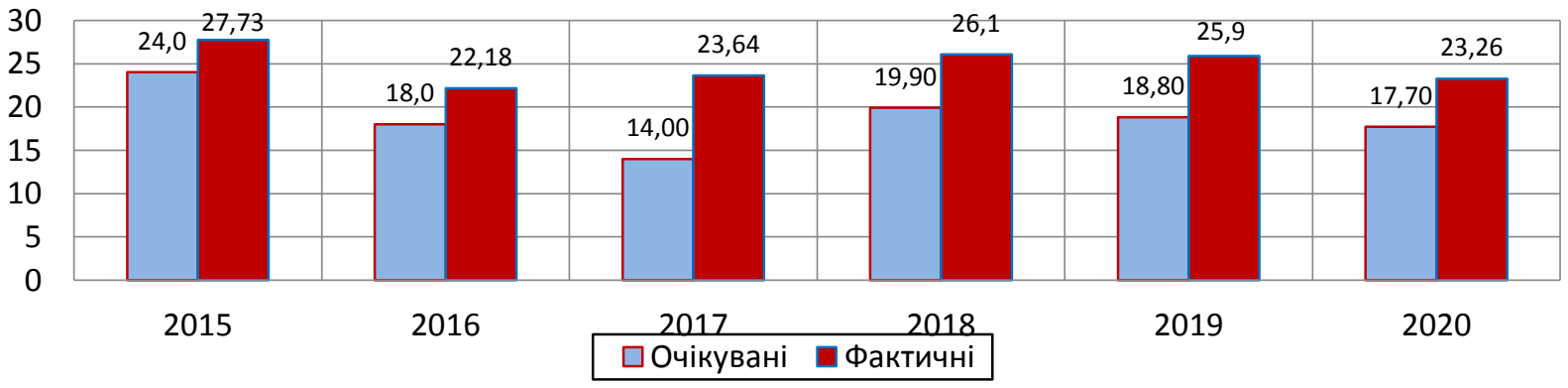

в)

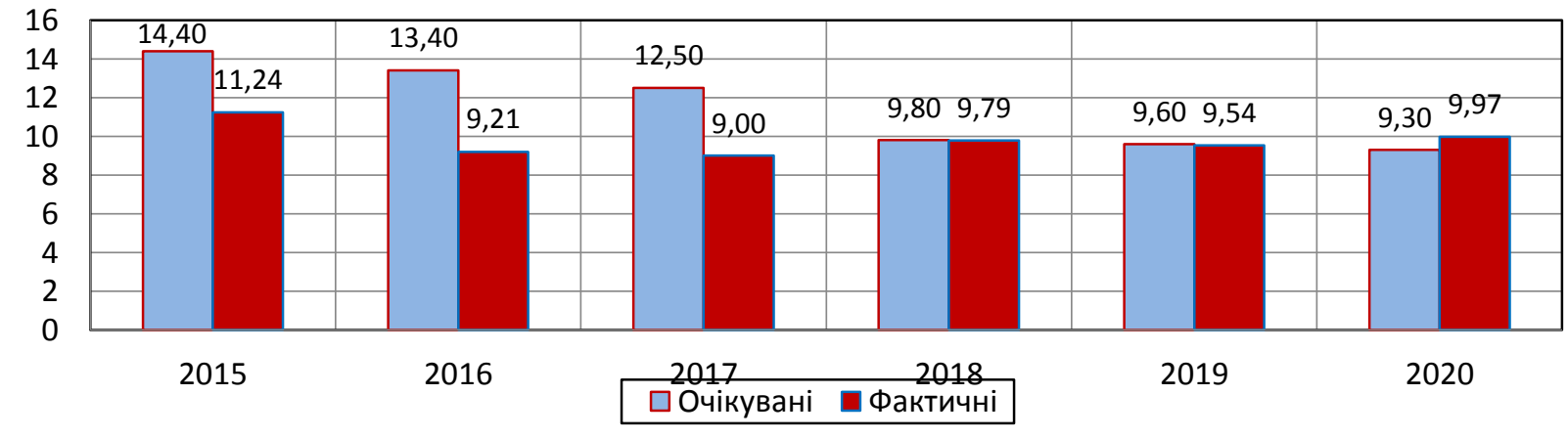

г)

Рисунок 1 - Порівняння очікуваних і фактичних відносних показників аварійності: а - кількість загиблих внаслідок ДТП на 100 тис. населення; б - кількість травмованих внаслідок ДТП на 100 тис. 
населення; в - кількість загиблих внаслідок ДТП на 100 тис. транспортних засобів; г - кількість загиблих внаслідок ДТП на 100 постраждалих

Таблиця 3 - Фактичні і очікувані показники рівня тяжкості наслідків дорожньо-транспортних пригод за роками [14].

\begin{tabular}{|c|c|c|c|c|c|c|c|c|c|}
\hline \multirow[t]{2}{*}{$\begin{array}{l}\text { Найменуван } \\
\text { ня завдання }\end{array}$} & \multirow[t]{2}{*}{$\begin{array}{c}\text { Найменування показників } \\
\text { виконання завдання }\end{array}$} & \multicolumn{5}{|c|}{ Значення фактичного показника } & \multicolumn{3}{|c|}{$\begin{array}{c}\text { Значення } \\
\text { очікуваного } \\
\text { показника } \\
\end{array}$} \\
\hline & & 2016 & 2017 & 2018 & 2019 & 2020 & 2021 & 2022 & 2023 \\
\hline \multirow{2}{*}{\begin{tabular}{|l} 
Зменшення \\
рівня \\
тяжкості \\
наслідків \\
дорожньо- \\
транспортни \\
х пригод
\end{tabular}} & $\begin{array}{l}\text { Кількість загиблих внаслідок } \\
\text { дорожньо-транспортних пригод } \\
\text { на } \\
100 \text { дорожньо-транспортних } \\
\text { пригод } \\
\end{array}$ & 2,2 & 2,1 & 2,2 & 2,2 & 2,1 & 3,1 & 2,7 & 2,4 \\
\hline & $\begin{array}{l}\text { Кількість травмованих } \\
\text { внаслідок дорожньо- } \\
\text { транспортних пригод на } \\
100 \text { дорожньо-транспортних } \\
\text { пригод }\end{array}$ & 21,2 & 21,3 & 20,6 & 20,4 & 19,0 & 31,9 & 28,4 & 24,9 \\
\hline
\end{tabular}

Складається враження, що таблиця очікуваних показників для Державної програми підвищення рівня безпеки дорожнього руху в Україні на період до 2023 року формувалася у зворотному порядку: значення 2020 року приймалися на $30 \%$ більшими від значень 2023 року. Звичайно, за таких умов чергова програма підвищення рівня безпеки дорожнього руху може бути виконана.

Подібні висновки можна також зробити аналізуючи Національну транспортну стратегію України на період вже до 2030 року, що була схвалена розпорядженням КМ України від 30 травня 2018 р. №430-р [15]. Внаслідок запровадження стратегії очікується зменшення до 2030 року на 50\% рівня смертності та кількості травмованих у ДТП на 100 тис. населення. Іншими словами, якщо брати за базу 2017 рік, то число загиблих має складати 4, а травмованих 40-41 особа. Власне, це плани 2020 року, які не були виконані і перенесені на наступне десятиліття.

Разом $з$ тим, варто відзначити, що ситуація на українських дорогах не найгірша у порівнянні 3 іншими країнами. Всесвітня організація охорони здоров'я (윽) у 2018 році склала черговий рейтинг країн за смертністю у ДТП. 3 цією метою вони вирахували кількість смертей в аваріях на 100 тисяч населення i, як наслідок, поставили Україну з результатом 13,7 на 104 місце [16].

Згідно 3 отриманими результатами, показник України становить насправді 7,95 смертей на 100 тисяч населення, тому Україну можна віднести до країн з «низькою» кількістю смертей у ДТП і розмістити іiі у рейтингу на 137 місці між Литвою $(8,0)$ і Угорщиною $(7,8)$. Гірша ситуація, ніж в Україні, у сусідніх Польщі - 9,7 смертей і 125 місце, Білорусі - 8,9 і 132; краща в Чехії - 5,9 смерті і 149 місце, Франції - 5,51 і 155, Німеччині - 4,1 і 162. Найкраща ситуація у 2018 році була на Мальдівах, де на 100 тис. населення припадало 0,9 смертей, відповідно, 174 місце, найгірша - у Ліберії -35,9 смертей і перше місце у рейтингу ВОО3 [16].

Можна зрештою вітати прагнення України досягти показників ФРН навіть через 10 років, якби не було прикладу Японії. У 2015 році на іï дорогах загинуло менше 4 тисяч, а у 2020 році 2839 осіб та трапилося 320 тис. ДТП [17]. Це при тому, що населення Японії станом на 2020 рік становило 125,6 млн мешканців, а на 1000 японців припадає 591 автомобіль. Як зазначається у повідомленні: «...підвищення рівня безпеки на дорогах стало результатом роботи уряду і пов'язаних 3 ним організацій, а також зусиль кожного громадянина Японії» [17].

\section{ОБГОВОРЕННЯ РЕЗУЛЬТАТІВ ДОСЛІДЖЕННЯ}

Упродовж останніх десять років сфера забезпечення безпеки дорожнього руху не залишалася поза увагою держави про що свідчить ряд прийнятих документів, перелік яких наведено у таблиці 4.

Таблиця 4 - Перелік документів прийнятих, в Україні з метою підвищення рівня БДР

\begin{tabular}{|c|l|}
\hline Дата прийняття & \multicolumn{1}{|c|}{ Назва документа } \\
\hline Жовтень 2010 p. & Транспортна стратегія України на період до 2020 року \\
\hline Жовтень 2010 р. & $\begin{array}{l}\text { Державна цільова програма підвищення рівня безпеки дорожнього руху до } 2016 \\
\text { року }\end{array}$ \\
\hline
\end{tabular}




\begin{tabular}{|c|c|}
\hline Чep & підвищення рівня безпеки дорожнього руху в Україні на період до 2020 \\
\hline Кві & $\begin{array}{l}\text { Державна програма підвищення рівня безпеки дорожнього руху в Україні на } \\
\text { період } \\
\text { до } 2020 \text { року }\end{array}$ \\
\hline & \\
\hline & 9-2021 роки з реалізації Національної транспортної стратегії \\
\hline $\mathrm{p}$. & ення рівня безпеки дорожнього руху до 2024 року \\
\hline$\Gamma \mathrm{p}$ & $\begin{array}{l}\text { Державна програма підвищення рівня безпеки дорожнього руху в Україні н } \\
\text { період } \\
\text { до } 2023 \text { року }\end{array}$ \\
\hline
\end{tabular}

Однак проведений аналіз показав, що досягти запланованих результатів, за окремим виключенням, не вдалося. Більше того, дивним виглядає невідповідність між запланованими показниками аварійності і отриманими фактичними, коли перші перевищують останні, що повертає рівень аварійності у державі на кілька років назад.

Особливо це помітно на прикладі Японії, де навпаки останніми роками спостерігається прогрес. Так, в Україні станом на 01.01.2021 р. проживало 41,59 млн осіб, а на 1000 мешканців припадало 245 легковики $[8,11]$. Натомість, результати роботи українського уряду, пов'язаних 3 ним організацій та кожного українця зокрема, як видно 3 аналізу відносних показників аварійності, неспівмірні 3 японськими.

\section{ВИСНОВКИ}

Політика держави у сфері забезпечення БДР в останні десять років не призвела до відчутних результатів щодо зниження рівня аварійності на вітчизняних дорогах. Прийняті Стратегії та, на їх виконання, Державні програми підвищення рівня безпеки дорожнього руху в Україні, судячи за результатами проведеного аналізу, не були виконані. Фактичні показники соціального i транспортного ризиків у 2015-2020 роках були гірші за очікувані і лише кількість загиблих внаслідок ДТП на 100 постраждалих буле меншою або знаходилася на одному рівні.

Запровадження двох нових очікуваних показників оцінки рівня важкості наслідків ДТП на 2021-2023 роки викликають певне здивування: чомусь їх значення гірші за фактичні показники отримані у 2016-2020 роках. Так само дивують шляхи підвищення рівня безпеки дорожнього руху, закладені у Національній транспортній стратегії України на період до 2030 року, за якою очікується зменшення до 2030 року на 50\% рівня смертності та кількості травмованих у ДТП на 100 тис. населення. За своєю суттю - це плани 2020 року, що не були виконані і перенесені на наступні десять років.

\section{ПЕРЕЛІК ДЖЕРЕЛ ПОСИЛАННЯ}

1. Україна через ДТП в рік втрачає 70 млрд грн - MIУ. URL : https://prm.ua/ukrayina-cherezdtp-v-rik-vtrachaye-70-mlrd-grn-miu/ (дата звернення: 11.12.2020).

2. Статистика ДТП в Україні. URL : http://patrol.police.gov.ua/statystyka/ (дата звернення: 10.02.2021).

3. Транспортна стратегія України на період до 2020 року. Офіційний вісник Украӥни. 2010 р. № 92. C. 3280.

4. Державна цільова програма підвищення рівня безпеки дорожнього руху. Урядовий кур'єр. 2013. 08 трав. (№ 82).

5. Постанова Верховної Ради України Про Рекомендації парламентських слухань на тему: «Стан i перспективи забезпечення в Україні безпеки дорожнього руху». URL : https://zakon.rada.gov.ua/laws/show/1091-19\#Техt (дата звернення: 10.02.2021).

6. Стратегія підвищення рівня безпеки дорожнього руху в Україні на період до 2020 року: Розпорядження Кабінету Міністрів України від 14.06 .2017 р. №481-р. Офіційиий вісник Украӥни. 2017 p. № 59. С. 1808.

7. Постанова від 25 квітня 2018 р. № 435 «Про затвердження Державної програми підвищення рівня безпеки дорожнього руху в Україні на період до 2020 року». URL : https://zakon.rada.gov.ua/laws/show/en/435-2018-\%D0\%BF (дата звернення: 10.02.2021).

8. Чисельність населення України 3 2015 по 2020 pp. URL


https://index.minfin.com.ua/ua/reference/people/ (дата звернення: 11.03.2021).

9. Возраст автомобильного парка Украины на начало 2017 года. URL : http://carinfo.kiev.ua/ vozrast-avtomobilnogo-parka-ukrainy-2017 (дата звернення: 11.03.2021).

10. Чому бреше статистика ДТП в Україні. URL : https://www.autocentre.ua/ua/news/sobytie/chomu-breshe-statistika-dtp-v-ukrayini-45188.html (дата звернення: 11.03.2021).

11. В Киеве уровень автомобилизации превысил 400 авто на 1000 жителей. Когда будет как в Европе? URL : http://www.autoconsulting.com.ua/article.php?sid=48496 (дата звернення: 16.03.2021).

12. Міжнародний конгрес з безпеки на транспорті -

ДП «ДержавтотрансНДІпроект». URL : https://www.insat.org.ua/phpfiles/ other/news/111119/ (дата звернення: 15.03.2021).

13. Стратегія підвищення рівня безпеки дорожнього руху в Україні на період до 2024 року. Урядовий кур 'єр від 04.11.2020 - № 214.

14. Державна програма підвищення рівня безпеки дорожнього руху в Україні на період до 2023 року. URL : https://zakon.rada.gov.ua/laws/show/1287-2020-\%D0\%BF\#Text (дата звернення: 11.02.2021).

15. Національна транспортна стратегія України на період до 2030 року. URL : https://zakon.rada.gov.ua/laws/show/430-2018-\%D1\%80 (дата звернення: 11.02.2021).

16. Рейтинг стран по уровню смертности в ДТП. URL : https://nonews. co/directory/lists/countries/mortality-road-traffic (дата звернення: 11.03.2021).

17. Скарбик Павло. Японія домоглася найнижчого рівня смертності в ДТП у світі. URL : https:// uamotors.com.ua/news/38940 (дата звернення: 16.03.2021).

\section{REFERENCES}

1. Ukrayina cherez DTP v rik vtrachaye $70 \mathrm{mlrd}$ hrn - MIU. URL : https://prm.ua/ukrayina-cherezdtp-v-rik-vtrachaye-70-mlrd-grn-miu/ (data zvernennya: 11.12.2020).

2. Statystyka DTP v Ukrayini. URL : http://patrol.police.gov.ua/statystyka/ (data zvernennya: 10.02.2021).

3. Transportna stratehiya Ukrayiny na period do 2020 roku. Ofitsiynyy visnyk Ukrayiny. 2010 r. № 92.

S. 3280.

4. Derzhavna tsilova prohrama pidvyshchennya rivnya bezpeky dorozhnoho rukhu. Uryadovyy kurier. 2013. 08 trav. (№ 82).

5. Postanova Verkhovnoyi Rady Ukrayiny Pro rekomendatsiyi parlamentskikh slushaniy na temu: «Stan ta perspektyvy zabezpechennya v Ukrayini bezpeky dorozhnoho rukhu». URL : https://zakon.rada.gov.ua/laws/show/1091-19\#Text (data zvernennya: 10.02.2021).

6. Stratehiya pidvyshchennya rivnya bezpeky dorozhnoho rukhu v Ukrayini na period do 2020 roku: Rozporyadzhennya Kabinetu Ministriv Ukrayiny vid 14.06.2017 r. №481-r. Ofitsiynyy visnyk Ukrayiny. 2017 r. № 59. S. 1808.

7. Postanova vid 25 kvitnya 2018 r. № 435 «Pro zatverdzhennya Derzhavnoyi prohramy pidvyshchennya rivnya bezpeky dorozhnoho rukhu v Ukrayini na period do 2020 roku». URL : https://zakon.rada.gov.ua/laws/show/en/435-2018-\%D0\%BF (data zvernennya: 10.02.2021).

8. Chyselnist naselennya Ukrayiny z 1990 po 2019 rr. URL : https://index.minfin.com.ua/ua/reference/people/ (data zvernennya: 11.03.2021).

9. Vik avtomobilnoho parku Ukrayiny na pochatok 2017 roku.

URL : http://carinfo.kiev.ua/ vozrast-avtomobilnogo-parka-ukrainy-2017 (data zvernennya: 11.03.2021).

10. Chomu breshe statystyka DTP $\mathrm{v}$ Ukrayini. URL : https://www.autocentre.ua/ua/news/sobytie/chomu-breshe-statistika-dtp-v-ukrayini-45188.html (data zvernennya: 11.03.2021).

11. V Kiyeve uroven avtomobilizatsii prevysil 400 avto na 1000 zhiteley. Kogda budet kak v Yevrope? URL : http://www.autoconsulting.com.ua/article.php?sid=48496 (data zvernennya: 16.03.2021).

12. Mizhnarodnyy konhres z bezpeky na transporti -

DP «DerzhavtotransNDIproekt». URL : https://www.insat.org.ua/phpfiles/ other/news/111119/ (data zvernennya: 15.03.2021).

13. Stratehiya pidvyshchennya rivnya bezpeky dorozhnoho rukhu v Ukrayini na period do 2024 roku. Uryadovyy kurier vid 04.11.2020 - № 214.

14. Derzhavna prohrama pidvyshchennya rivnya bezpeky dorozhnoho rukhu v Ukrayini na period do 
2023 roku. URL : https://zakon.rada.gov.ua/laws/show/1287-2020-\%D0\%BF\#Text (data zvernennya: 11.02.2021).

15. Natsionalna transportna stratehiya Ukrayiny na period do 2030 roku. URL : https://zakon.rada.gov.ua/laws/show/430-2018-\%D1\%80 (data zvernennya: 11.02.2021).

16. Reytynh krayin za rivnem smertnosti v DTP. URL : https://nonews. co/directory/lists/countries/mortality-road-traffic (дата звернення: 11.03.2021).

17. Skarbyk Pavlo. Yaponiya domohlasya naynyzhchoho rivnya smertnosti v DTP u sviti. URL : https:// uamotors.com.ua/news/38940 (data zvernennya: 16.03.2021).

\section{V.Kyshchun. The accident rate on Ukrainian roads: expectations that did not come true}

The study aimed to determine the actual accidents' state indicators on domestic roads and compare them with the expected, which were approved in the State programs to improve road safety for the periods up to 2016 and 2020, as well as analysis of expected indicators given in the State program level of road safety for the period up to 2023 .

The state of the accident was assessed by such indicators as the number of dead and injured per 100 thousand population (social risk), the number of dead per 100 thousand vehicles (transport risk), as well as three indicators that characterize the severity of the accident: the number of deaths per 100 injured and the number of fatalities and injuries per 100 traffic accidents. In the process of research, were determined the actual accident rates in Ukraine in 2015-2020. As a result, it was found that the actual indicators of social and transport risks in these years were worse than expected except only the number of deaths due to road accidents per 100 victims was less or was at the same level.

Some irrelevances between the planned expected results are observed in the State Program for Improving Road Safety in Ukraine for the period up to 2023. If we compare the numbers of adjacent 2020 and 2021, the expected results on three indicators have increased unjustifiably and only the number of deaths due to road accidents per 100 victims in 2021 and subsequent years is expected to be lower. An even greater irrelevance is observed when comparing the actual figures for 2020 with the expected ones for 2021; the Ukrainian roads' situation predicts to become worse than it is. Similarly irrelevant are the two new indicators that assess the severity of the accidents' consequences - the number of dead and injured per 100 accidents.

In Ukraine, the statistics on the death and injury of people as a result of road traffic accidents remains quite high, as for the European region. Analysis of the state of accidents on domestic roads for 2015-2020 showed that three out of four State road safety improving programs' indicators have not been implemented, and the planned accident indicators will not help improve the situation in the field of road safety.

Keywords: road safety, transport strategy, state programs, accident reduction, expected accident rates, actual accident rates.

КИЩУН Володимир Андрійович, кандидат економічних наук, доцент кафедри автомобілів і транспортних технологій, Луцький національний технічний університет, e-mail: kyshchun52@ukr.net. http://orcid.org/0000-0003-4019-8034.

Volodymyr KYSHCHUN, PhD. in Economic, Assoc. Professor of Motor Cars and Transport Technologies Department, Lutsk National Technical University, e-mail: kyshchun52@ukr.net. http://orcid.org/0000-0003-4019-8034.

DOI 10.36910/automash.v1i16.509 